\title{
National Numeracy Network Officers and Board of Directors
}

Milo Schield

Augsburg University, milo@pro-ns.net

Follow this and additional works at: https://digitalcommons.usf.edu/numeracy

Part of the Curriculum and Instruction Commons, Other Applied Mathematics Commons, Scholarship of Teaching and Learning Commons, and the Science and Mathematics Education Commons

\section{Recommended Citation}

Schield, Milo. "National Numeracy Network Officers and Board of Directors." Numeracy 14, Iss. 1 (2021): Article 13. DOI: https://doi.org/10.5038/1936-4660.14.1.1389 


\title{
National Numeracy Network Officers and Board of Directors
}

\author{
Abstract \\ National Numeracy Network Officers and Board of Directors in the year 2020. \\ Creative Commons License \\ (c) (i) (9)
}

This work is licensed under a Creative Commons Attribution-Noncommercial 4.0 License 


\title{
National Numeracy Network Officers and Board of Directors
}

\author{
Elected Officers \\ President \\ MILO SCHIELD, Augsburg University \\ Vice President \\ LUKE TUNSTALL, Trinity University \\ Past President \\ ERIC GAZE, Bowdoin College \\ Secretary/Treasurer \\ MARC ISAACSON, Augsburg University \\ Elected Board of Directors \\ CAROL ANN DAVIS, University of South Florida \\ KATHERINE FOLLETTE, Amherst College \\ SARAH HOILAND, Hostos Community College \\ LAUREN NELSON, Democracy Prep Public Schools \\ VICTOR PIERCY, Ferris State University \\ ALISA ROD, Barnard College \\ MONIKA SIKAND, Bronx Community College of the City University of New York \\ Ex Officio Members \\ NATHAN GRAWE (as Executive Editor of Numeracy), Carleton College
}

